\title{
THE EFFECT OF PECTIN AND PECTIN NANOPARTICLES ON SOME QUALITY PROPERTIES OF MEAT SAUSAGE
}

\author{
MAHMOUD. F. S. A. KODOUS
}

\author{
Meat \& Fish Technol. Res. Dept., Food Technology Research Institute, Agricultural \\ Research Center, Giza, Egypt.
}

(Manuscript received 1 July 2019)

Abstract
ne aim of this work was to investigate the possibility of using
nanoparticles pectin as active colloidal systems in meat sausage.
nanoparticles as active colloid on the quality properties of the
physicochemical, texture profile and sensory evaluation of meat sausage
were investigated. The results showed that the particle sizes were
decreased with decreasing the concentrations of pectin. The obtained
results indicated that the best water holding capacity (lowest value),
plasticity, cooking loss, cooking yield, emulsion stability, texture profile
analysis and sensory evaluation were recorded in the nanoparticles
pectin sausage samples (P6,P5 and P4) when compared to the ordinary
pectin sausage samples (P3,P2 and P1) and control samples (C).
Keywords: colloid, pectin nanoparticles, meat products, meat sausage

\section{INTRODUCTION}

The meat sausages are one form of processed beef which is currently quite popular in the community. Sausages are also familiar as one of the ready-to-eat breakfast menu items among schoolchildren. The sausage meat is a food product derived from a mixture of delicate meat (containing meat not less than 60\%) with flour or starch with or without the addition of seasonings and food additives as otherwise permitted and put into sausage casings mentions that the main component of the sausage consists of meat, fat, and water. In addition, the sausages also add additional ingredients such as salts, phosphates, preservatives, coloring, ascorbic acid, protein isolates, and carbohydrates, this lead to need to some material such as Hydrocolloids which have a wide array of functional properties in foods. These include thickening, gelling, emulsifying, stabilization in this products. (Dipjyoti and Suvendu 2010 and Badan Standardisasi Nasional.,1995).

Hydrocolloids have a wide array of functional properties in foods. These include thickening, gelling, emulsifying, stabilization (Dipjyoti and Suvendu 2010). An association colloid is a colloid whose particles are made up of even smaller molecules. Used for many years to deliver polar, nonpolar, and amphiphilic functional ingredients (Bilska et al., 2009). Though all hydrocolloids thicken aqueous dispersions, only a comparatively few gums form gels. Also the gels thus formed vary widely in gel character and texture. Hence, knowledge of the conditions required for gelling of particular hydrocolloid dispersion, the characteristics of the gel produced and the 
texture it confers are very important aspects to design a specific food formulation. The important gums that find application in food as gelling agents include alginate, pectin, carrageenan, gellan, gelatin, agar, modified starch, methyl cellulose and hydroxypropylmethyl cellulose (Williams 2006).

Pectin is a natural, non toxic and amorphous carbohydrate present in cell wall of all plants tissue and is the secondary product of fruit juice, sunflower oil industries, therefore it is inexpensive, abundantly available, ecofriendly biodegradable product and most important it act as stabilizing agent. Pectin has ability to bind with some organic and inorganic substances via molecular interactions (Liu et al., 2003). Ideal biobased and biodegradable polymers are defined as materials that are produced from renewable resources and completely degraded to carbon dioxide and water by the action of micro-organisms. Pectins are anionic, soluble, non-starch polysaccharides extracted from the primary cell walls of plants. Pectins, a heterogeneous complex polysaccharide of linear 1,4-linked a-D-galacturonic acid are used as gelling and thickening agents in food industries In recent years, the polymer has also been explored as a pharmaceutical excipientm. The functional properties of pectin are determined by the percentage of carboxyl groups that have been esterified or amidated, denoted as the degree of esterification (DE) and degree of amidation (DA), respectively. Amidated low-methoxy pectin ( $D E<50 \%$ ) forms more rigid gels by the action of calcium, which cross-links the galacturonic acid chains, than does only methoxy pectin. The lower the $D E$, the more sensitive the pectin to calcium. Several researchers successfully incorporated protein or peptide into calcium pectinate beads for a colonic delivery system (Rolin et al., 1993 ; Pillay and Fassihi ,1999 and Praneet et al.,2008).

Nanotechnology may be able to create many new materials with a vast range of applications. The interesting and sometimes unexpected properties of nanoparticles are largely due to the huge surface area of the material accompanied usually by an increase in stability and improved functionality which dominates the contributions made by the small bulk of the material. (Sangeetha et al., 2010 and Kim et al., 2010) Nanotechnology allows to measure, control, and manipulate matter at the nanoscale level to change those properties and functions in a beneficial way. Developments in nanotechnology are driven by fundamental and applied research in physics, chemistry, biology, engineering, and materials science. Nanotechnology provides the tools to measure and understand biosystems in science and technology platform. The potential benefits of nanofoods are astonishing. Advocates of the technology promise improved food processing, packaging and safety; enhanced flavor and nutrition; 'functional foods' where everyday foods carry medicines and supplements, and 
increased production and cost-effectiveness. In a world where thousands of people starve each day, increased production alone is enough to warrant worldwide support. For the past few years, the food industry has been investing millions of dollars in nanotechnology research and development. Some of the world's largest food manufacturers, including Nestle, Altria, H.J. Heinz and Unilever, are blazing the trail, while hundreds of smaller companies follow their lead. Yet, despite the potential benefits, compared with other nanotechnology arenas, nanofoods don't get a lot of publicity. Applications of nanotechnology within the food industry are beginning to impact the important aspects of food and associated industries from food safety to the molecular synthesis of new food products and ingredients (Chen et al. 2006). The fact that systems with structural features on the nanoscale have physical, chemical, and biological properties substantially different from their macroscopic counterparts is changing the understanding of biological and physical phenomena in food systems.

The present study aims to utilize the positive effect of nanotechnology in the production of pectin nanoparticles, which have a multiplier effect in linking the components of meat sausage, and improving the quality properties of the physicochemical and sensory products of meat

\section{MATERIALS AND METHODS}

\section{Materials}

Meat and fat were obtained from local supermarket at Giza, Egypt, immediately transported using an ice box to the laboratory of Meat and Fish Technology Department, Food Technology Research Institute, Giza, Egypt. Meat and fat were kept at $-18{ }^{\circ} \mathrm{C}$ until using it. Salt, spices, garlic powder were purchased from local market at Giza, Egypt. Defatted soy flour was obtained from the Unit of Soybean Processing in Food Technology Research. Pure pectin and food grade sodium tripoly phosphate (99.5\% purity) were obtained from El-Gomhouria Co. for Trading pharmaceutical, Chemicals and Medical Equipments, Cairo, Egypt.

\section{Methods}

\section{Preparation of Pectin nanoparticles .}

Pectin nanoparticles were prepared by an ionic gelation of cation $\left(\mathrm{CaCl}_{2}\right)$ and pectin as described by Praneet et al., (2008). Briefly, pectin was dissolved in distilled water at $80^{\circ} \mathrm{C}$ up to completely dissolving and allowed to cool at room temperature to a concentration ranging from $1.0 \%, 3.0 \%$ and $5.0 \%$ solutions. The divalent cation $\left(\mathrm{CaCl}_{2}\right)$ was dissolved in distilled water to a concentration of $1.0 \%, 3.0 \%$ and $5.0 \%$ solutions . Nanoparticles were prepared by drop-wise addition of pectin solution to a divalent cation $\left(\mathrm{Ca} \mathrm{Cl}_{2}\right)$ solution while the solution was stirred under magnetic stirring $1000 \mathrm{rpm}$ for $90 \mathrm{~min}$ at room temperature (the ratio of $\mathrm{Ca}^{\mathrm{Cl}_{2}}$ to pectin was $1: 1$ ). 


\section{Meat sausage preparation:}

The meat was washed and cut then minced and mixed with other ingredients (minced meat $60 \%$, fat $17.0 \%$,water $15.0 \%$, soy protein $5 \%$, sodium tryployphosphate $0.3 \%$, salt $1.5 \%$, garlic powder $0.2 \%$ and spices $1.0 \%$ ), then divided into seven treatments and the suitable units of water were added to the mixture and the same an unit was replaced with calcium pectinate $5 \%$ by different percentages, so that the percentage of pectin in the final mixture is showed in table (1). Each group of samples were mixed well then stuffing into sausage casing by the filling machine then packaged it in foam dishes then wrapping by polyethylene bags and stored at $-18^{\circ} \mathrm{C}$ until analysis.

Table 1. The composition of different sausage treatments

\begin{tabular}{|c|c|}
\hline Sample & Treatments \\
\hline Control (C) & Without pectin \\
\hline P1 & $0.5 \%$ pectin \\
\hline P2 & $0.75 \%$ pectin \\
\hline P3 & $1.0 \%$ pectin \\
\hline P4 & $0.5 \%$ nano pectin \\
\hline P5 & $0.75 \%$ nano pectin \\
\hline P6 & $1.0 \%$ nano pectin \\
\hline
\end{tabular}

\section{Scanning Transmission Electron Microscopy(TEM):}

The surface morphology of pectin nanoparticles was investigated using Transmission Electron Microscope (TEM). Polymer sample was suspended in acetone for $20 \mathrm{~min}$, then a drop of the suspension was placed on a grid and the solvent evaporated prior to imaging .

\section{Rheological properties.}

Rheological parameters (shear rate and viscosity) of pectin and pectin nanoparticales were measured at different temperatures using Brookfield Engineering labs DV-III Ultra Rheometer. The samples were placed in a small sample adaptor and a constant temperature water bath was used to maintain the desired temperature. The viscometer was operated between 10 and $50 \mathrm{rpm}$ and shear stress, shear rate and viscosity data were directly obtained from the instrument, the SC4-21 spindle was selected for the measurement tests.

\section{Physiochemical evaluation:}

The water holding capacity (WHC) and plasticity were measured by filter press methods of Soloviev (1966). Cooking loss of samples was calculated as percentage of weight change from raw to cooked state Cooking yield was determined according to Osheba(2013) . pH value was determined to Aitken, et al.,( 1962). 
Emulsion stability (ES) was determined using model systems, as described by Ockerman (1985) and Zorba et al., (1993). $10 \mathrm{~g}$ of emulsion was weighed into a centrifuge tube capped and immediately heated at $80^{\circ} \mathrm{C}$ in a water bath for $30 \mathrm{~min}$. The tubes were centrifuged at $900 \mathrm{rpm}$ for $15 \mathrm{~min}$ and the amounts of water and oil separated were measured, and ES was calculated using the following equations:

$\mathrm{ES} \%=100-(\mathrm{SW})$

$\mathrm{SW}=\mathrm{g}$ of water separated $\mathrm{x} 10$

\section{Texture Profile Analysis:}

Texture Profile Analysis was determined according to Bourne (2003).

\section{Sensory evaluation:}

Sensory evaluation was determined according to Suderman et al., (1981). Immediately after meat sausage manufacturing the samples were prepared by cooking in boiling water for 10 min and subjected to member's trained sensory panel to evaluate color, odor, texture and overall acceptability of these formulas.

\section{Statistical analysis:}

The obtained data were exposed to analysis of variance followed by multiple comparisons between means $(P \leq 0.05)$ applying $L S D$. The analysis was carried out using the PRO ANOVA procedure of Statistical Analysis System (SAS, 1996).

\section{RESULTS AND DISCUSSION}

\section{Scanning Transmission Electron Microscopy (TEM)}

TEM is a powerful tool to understand the morphology as well as particle size of nanomaterials. Three different concentrations (1.0,3.0 and 5.0\%) with the same ratio (1:1) of pectin $/ \mathrm{CaCl}_{2}$ were used. Transmittance Electron Microscope instrument was used for the determination of the particle size and the morphological structure of the prepared polymer matrix. In general, the synthesized Ca-pectinate were spherical in morphology without forming any agglomerates. The average particle size at $1.0 \%$ of the Ca-pectinate solution concentration was 2.3 to $6.2 \mathrm{~nm}$. At a Ca-pectinate concentration of $3.0 \%$, The average particle size was between 2.86 to $7.4 \mathrm{~nm}$, the average particle diameter increased to $9.5 \mathrm{~nm}$ the Ca-pectinate concentration was further increased to $5.0 \%$, it is clear that at $5.0 \%$ Ca-pectinate concentration, the average particle size was $9.5 \mathrm{~nm}$ and the morphology was still comparable with those synthesized using 1.0 and $3.0 \%$ Ca-pectinate solutions. it is clear that all concentrations $(1.0,3.0$ and $5.0 \%$ ) of Ca-pectinate were less than $10 \mathrm{~nm}$.

From Figure (2) it was observed that the spacing between the curves of pectin and pectin nanoparticles solutions was increased by increasing the concentration of pectin and calcium chloride, this may be due to the structural change in samples as shown in Figure (1), this was confirmed with the obtained results by Entsar et al., (2012). 

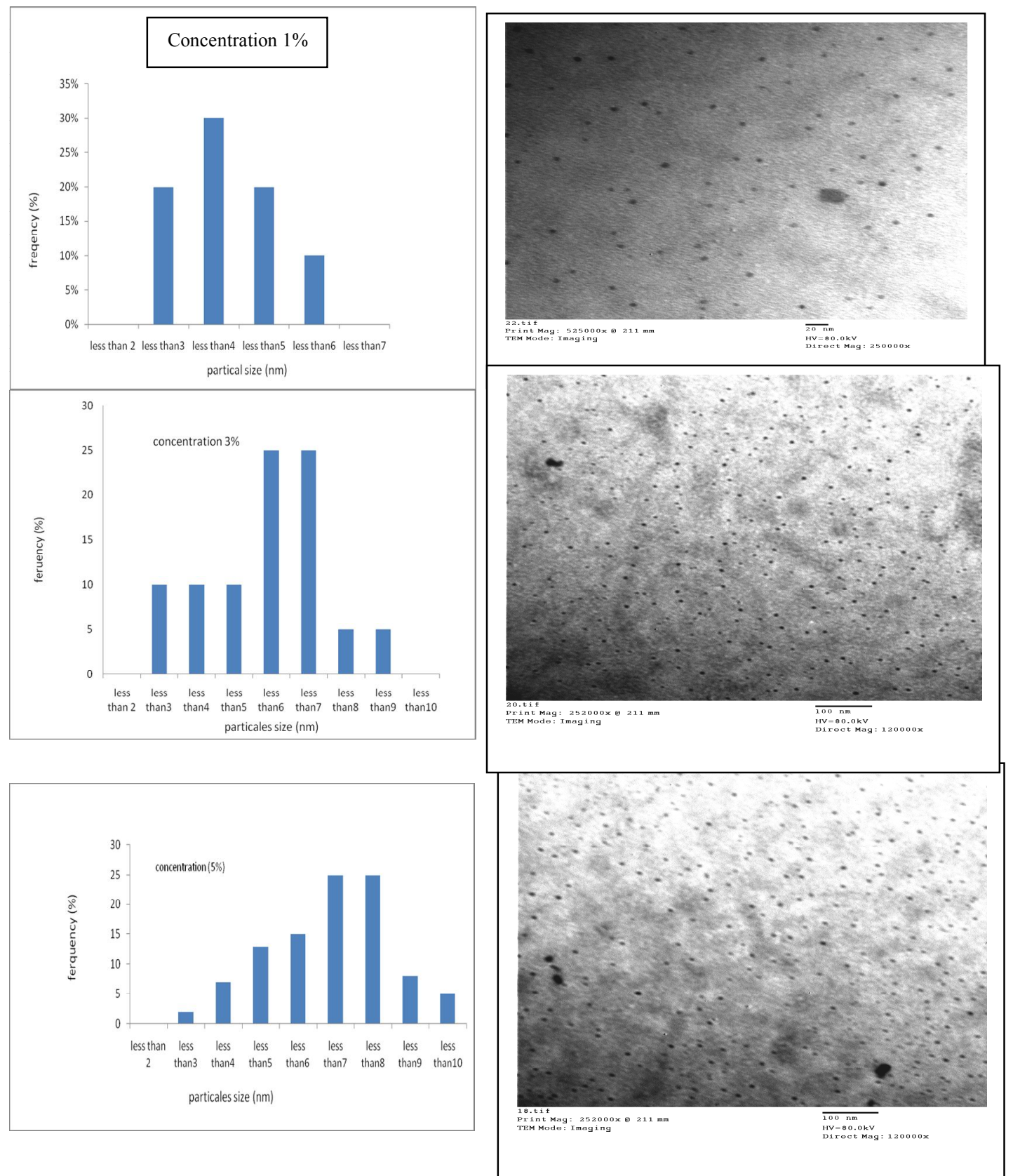

Fig. 1. TEM images of Ca-pectinate prepared using Ca-pectinate solutions of $1.0 \%, 3.0$ and $\%$ and $5.0 \%$ Graphs shows the particle size distribution of each sample based on TEM images 


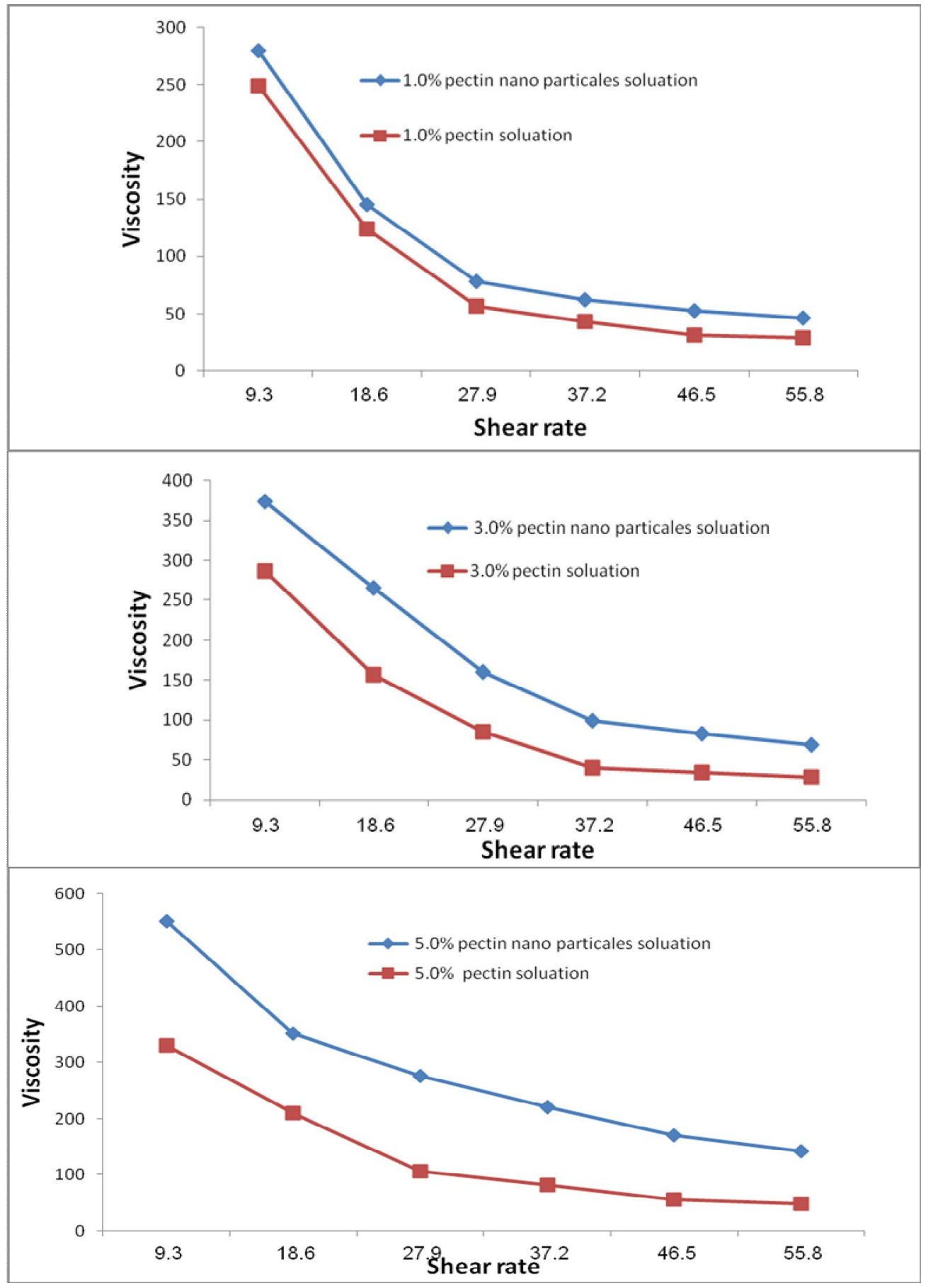

\section{Viscosity $=$ Paskal in second (Pa.s)}

Fig. 2. Effect of shear rate on apparent viscosity of ordinary pectin and nano particales pectin solutions at different concentrations. 


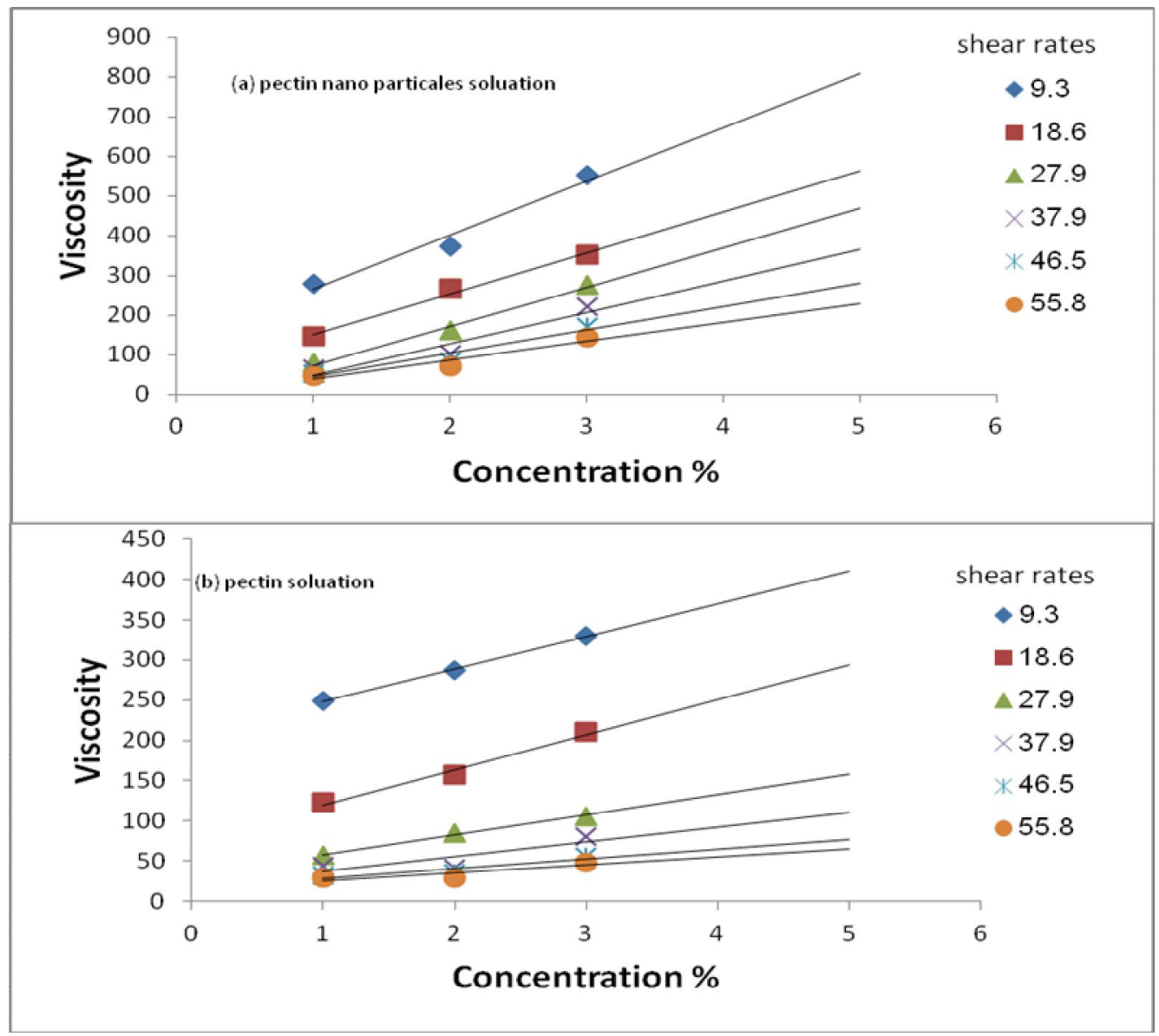

\section{Viscosity $=$ Paskal in second (Pa.s)}

Fig. 3. Effect of Concentration on the apparent viscosity of ordinary pectin and nano particales pectin solutions at different shear rates.

Figure (3-a) shows the effect of different concentrations of pectin solutions on the apparent viscosity. the effect of soluble solid contents on the apparent viscosity of pectin solutions at different shear rates $(9.3,18.6,27.9,37.9$ and 46.5 sec-1) were studied, the results indicated that by increasing the concentration of pectin the apparent viscosity increased at all shear rates studied.

Figure (3-b) shows the effect of different concentrations of pectin nanoparticles solutions on the apparent viscosity at different shear rates and it can be seen that the same trend was observed. The results indicate that the apparent viscosities of pectin nanoparticles decreased than the apparent viscosity of pectin solutions this is because calcium chloride -crosslinked pectin molecules turned into more dense particles whose hydrodynamic volumes were smaller than pure pectin chains. Fewer free pectin chains and more cross linked chains resulted in a decrease in total hydrodynamic volumes of pectin. When the total hydrodynamic volume of pectin is smaller than the solution volume, pectin chains do not entangle with each other. Li, Huang, (2012). 
Table 2. Physiochemical properties of different sausage treatments before cooking.

\begin{tabular}{|c|c|c|c|}
\hline Treatments & W.H.C $\left(\mathrm{cm}^{2}\right)$ & Plasticity $\left(\mathrm{cm}^{2}\right)$ & PH \\
\hline C & $1.60^{\mathrm{a}} \pm 0.4$ & $3.70^{\mathrm{e}} \pm 0.25$ & $6.20^{\mathrm{a}} \pm 0.1$ \\
\hline P1 & $1.36^{\mathrm{ab}} \pm 0.42$ & $3.95^{\mathrm{e}} \pm 0.15$ & $6.20^{\mathrm{a}} \pm 0.1$ \\
\hline P2 & $1.26^{\mathrm{ab}} \pm 0.14$ & $4.30^{\mathrm{d}} \pm 0.1$ & $5.90^{\mathrm{b}} \pm 0.13$ \\
\hline P3 & $1.18^{\mathrm{ab}} \pm 0.1$ & $4.50^{\mathrm{d}} \pm 0.15$ & $5.90^{\mathrm{b}} \pm 0.1$ \\
\hline P4 & $1.10^{\mathrm{bc}} \pm 0.1$ & $4.80^{\mathrm{c}} \pm 0.1$ & $6.21^{\mathrm{a}} \pm 0.1$ \\
\hline P5 & $0.95^{\mathrm{bc}} \pm 0.1$ & $5.10^{\mathrm{b}} \pm 0.1$ & $6.22^{\mathrm{a}} \pm 0.1$ \\
\hline P6 & $0.80^{\mathrm{c}} \pm 0.1$ & $5.40^{\mathrm{a}} \pm 0.15$ & $6.27^{\mathrm{a}} \pm 0.05$ \\
\hline LSD & 0.4186 & 0.2642 & 0.1750 \\
\hline
\end{tabular}

means that the values followed by the same letter in the same a column are not - significantly different at $(P \leq 0.05)$

\section{W.H.C: Water holding capacity.}

Data presented in table (2) pointed the water holding capacity (W.H.C) , Plasticity and $\mathrm{pH}$ before cooking, it could noticed that water holding capacity and plasticity of different sausage treatments were significantly $(p<0.05)$ affected by the type of pectin immediately after processing. The best water holding capacity (i.e., lowest value) and plasticity was recorded for treatment P6 P5,P4,P3,P2,P1 and C,respectively . These results are in agreement with that reported by Osheba et al., (2013) found that addition of pectin improved the water holding capacity and plasticity of raw meat sausage. But on the other hand the treatments which contained the pectin nanoparticles were better when compared to the treatments which contained the normal pectin. This may be due to nanoparticles caused largely huge surface area of the material accompanied usually by an increase in stability and improved functionality which dominates the contributions made by the small bulk of the material. (Sangeetha et al., 2010 and Kim et al., 2010), therefore the effect nanotechnology increases the surface area exposed to the pectin nanoparticles and thus increases its effectiveness in linking the meat sausage components (deliver polar, nonpolar, and amphiphilic functional ingredients, Bilska et al., 2009). and increasing the efficiency with increasing the concentration of pectin. it could be noticed that The results pointed that the $\mathrm{pH}$ of different sausage treatments were non significantly $(p<0.05)$ affected by the type of pectin excepted treatment $p 3$, although $\mathrm{pH}$ of The treatments added to it the pectin nanoparticles was higher than when compared to the treatments which contained the normal pectin and C,this may be due to effect of calcium ion which increase the $\mathrm{pH}$ of treatments which contained the pectin nanoparticles. 
Table 3. Physiochemical properties of different cooked sausage treatments

\begin{tabular}{|c|c|c|c|}
\hline Treatments & W.H.C $\left(\mathrm{cm}^{2}\right)$ & Plasticity $\left(\mathrm{cm}^{2}\right)$ & pH \\
\hline C & $2.35^{\mathrm{a}} \pm 0.1$ & $2.38^{\mathrm{e}} \pm 0.2$ & $6.26^{\mathrm{c}} \pm 0.1$ \\
\hline P1 & $2.30^{\mathrm{ab}} \pm 0.15$ & $2.65^{\mathrm{d}} \pm 0.25$ & $6.22^{\mathrm{c}} \pm 0.11$ \\
\hline P2 & $2.21^{\mathrm{b}} \pm 0.15$ & $2.71^{\mathrm{d}} \pm 0.2$ & $6.2^{\mathrm{c}} \pm 0.1$ \\
\hline P3 & $2.18^{\mathrm{b}} \pm 0.11$ & $2.96^{\mathrm{c}} \pm 0.15$ & $6.21^{\mathrm{c}} \pm 0.11$ \\
\hline P4 & $1.8^{\mathrm{c}} \pm 0.14$ & $3.1^{\mathrm{ab}} \pm 0.22$ & $6.31^{\mathrm{b}} \pm 0.08$ \\
\hline P5 & $1.78^{\mathrm{c}} \pm 0.11$ & $3.33^{\mathrm{a}} \pm 0.18$ & $6.35^{\mathrm{b}} \pm 0.1$ \\
\hline P6 & $1.76^{\mathrm{c}} \pm 0.1$ & $3.38^{\mathrm{a}} \pm 0.12$ & $6.41^{\mathrm{a}} \pm 0.09$ \\
\hline LSD & 0.0382 & 0.2370 & 0.0478 \\
\hline
\end{tabular}

means that the values followed by the same letter in the same a column are not - significantly different at $(P \leq 0.05)$

\section{W.H.C: Water holding capacity.}

It could be noticed from the results in Table (3) that water holding capacity (W H C) and plasticity were reduced in all treatments after cooking,this may be due to partial denaturation of the protein causes shrinkage in the volume of myofibrillar spacing. This denaturation is exacerbated with high temperatures and led to lost of water holding capacity (W H C) and plasticity. The results pointed also that the water holding capacity and plasticity of different sausage treatments were significantly $(p<0.05)$ affected by the type of pectin. It could be observed that treatments which the pectin nanoparticles added to it were had The best water holding capacity (as quality properties) and plasticity after cooking when compared to the treatments which it the normal pectin added to and C,respectively, and increases the efficiency by increasing the concentration of pectin, this due to The small micro reticulated fibers form an extremely was stable gel compared with pectin (Bodner and Sieg,2009).

The results of the same table showed that the $\mathrm{pH}$ of different sausage treatments after cooking were significantly $(p<0.05)$ affected by the type of pectin, $\mathrm{pH}$ increased in all treatments, this may be due to the effect of the high temperature on protein. $\mathrm{pH}$ of the nanoparticles pectin samples was higher than the ordinary pectin samples and $C$. This may be due to the effect of calcium ion which increase the $\mathrm{pH}$ of the nanoparticles pectin samples. These results are in agreement with that reported by Gençcelep et al., (2017) who found that pH had a profound effect on physical properties such as the water-holding capacity, tenderness and color of meat. Usually, a high $\mathrm{pH}(\sim 6.80)$ is closely related to high shear force or gel strength in meat products as found in Tables (2 and 3). 
Results in table (4) indicated that there were significant differences $(P \leq 0.05)$ in cooking loss and cooking yield of different treatments nanoparticles pectin samples and the treatments the ordinary pectin samples and C,Whereas, P6 had the lowest level of cooking loss and the highest level in cooking yield 12.5 and $87.5 \%$ followed by P5,P4, P2,P2,P2,P1 and C, which recorded 12.8 and 87.2,13.1 and 86.0,14.1 and 85.9,15.1 and 84.9,15.9 and 84.1 and 22.35 and 77.65,respectively. This may be due to that treatments which the nanoparticles pectin samples were The best in water holding capacity (i.e., lowest value) and plasticity as in tables ( 2 and 3). This result in less lost water amounts during cooking process when compared with the treatments the ordinary pectin samples and $\mathrm{C}$.

Table 4. Cooking loss, cooking yield and Emulsion stability (ES) of different cooked sausage treatments .

\begin{tabular}{|c|c|c|c|}
\hline Treatments & Cooking loss (\%) & cooking yield (\%) & ES \\
\hline C & $22.35^{a} \pm 2.0$ & $77.65^{\mathrm{d}} \pm 1.9$ & $78.95^{\mathrm{d}} \pm 1.45$ \\
\hline P1 & $15.90^{\mathrm{b}} \pm 1.5$ & $84.1^{\mathrm{c}} \pm 1.35$ & $83.92^{\mathrm{c}} \pm 1.35$ \\
\hline P2 & $15.10^{\mathrm{bc}} \pm 1.5$ & $84.9^{\mathrm{bc}} \pm 1.3$ & $84.7^{\mathrm{bc}} \pm 1.30$ \\
\hline P3 & $14.10 \mathrm{~b}^{\mathrm{c}} \pm 1.3$ & $85.9^{\mathrm{abc}} \pm 1.3$ & $85.32^{\mathrm{abc}} \pm 1.3$ \\
\hline P4 & $13.10^{\mathrm{c}} \pm 1.0$ & $86.0^{\mathrm{ab}} \pm 0.7$ & $86.66^{\mathrm{ab}} \pm 1.11$ \\
\hline P5 & $12.80^{\mathrm{a}} \pm 0.9$ & $87.2^{\mathrm{a}} \pm 0.7$ & $86.97^{\mathrm{ab}} \pm 1.11$ \\
\hline P6 & $12.50^{\mathrm{c}} \pm 0.9$ & $87.5^{\mathrm{a}} \pm 0.7$ & $87.38^{\mathrm{a}} \pm 1.13$ \\
\hline LSD & 2.3689 & 2.12245 & 2.1998 \\
\hline
\end{tabular}

means that the values followed by the same letter in the same a column are not - significantly different at ( $P \leq \mathbf{0 . 0 5})$

From the obtained results in table (4) it could be noticed that there were significant differences $(P \leq 0.05)$ in emulsion stability of different treatments which contained the nanoparticles pectin and the treatments the ordinary pectin samples and $\mathrm{C}$ samples, Whereas, P6 had the highest emulsion stability value followed by $\mathrm{P} 5, \mathrm{P} 4, \mathrm{P} 3, \mathrm{P} 2, \mathrm{P} 1$ and $\mathrm{C}$ samples, respectively.this may be due to $\mathrm{pH}$ effect as in table (3)that comfirmed by Cheftel et al.,(1985) who reported that pH was one of the most important parameters affecting emulsion characteristics. $\mathrm{pH}$ influences the emulsification properties of the proteins of the meat species. At the isoelectric point of proteins, hydrophobic interactions between lipids and proteins are enhanced. Myofibrillar proteins have better emulsifying properties at $\mathrm{pH}$ values further away from the isoelectric point. Stability is the most important factor to be considered in emulsion technology. Emulsion stability is an indicator of unseparated fat and moisture retained by meat proteins. When oil content is reduced, and droplet concentration decreases, creaming velocity increases. Thus, polysaccharides are added to food emulsions to stabilize emulsion droplets against creaming and to modify their texture properties (McClement, 2000 and Tahmasebi et al., 2016). 
Table 5. Texture profile analysis (TPA) of different cooked sausage treatments

\begin{tabular}{|c|c|c|c|c|c|c|}
\hline 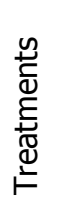 & $\begin{array}{l}\text { Hardness } \\
\text { (N) }\end{array}$ & $\begin{array}{c}\text { Cohesiveness } \\
\text { (N) }\end{array}$ & $\begin{array}{c}\text { Gumminess } \\
\left(\mathrm{N} / \mathrm{mm}^{2}\right)\end{array}$ & $\begin{array}{c}\text { Chewiness } \\
(\mathrm{N} / \mathrm{mm})\end{array}$ & $\begin{array}{l}\text { Springiness } \\
(\mathrm{mm})\end{array}$ & $\begin{array}{c}\text { Adhesiveness } \\
\text { (N.sec) }\end{array}$ \\
\hline $\mathrm{C}$ & $\begin{array}{c}21.86^{\mathrm{a}} \\
\pm 2.1\end{array}$ & $\begin{array}{l}0.43^{b} \\
\pm 0.2\end{array}$ & $\begin{array}{c}12.12^{b} \\
\pm 2.3\end{array}$ & $\begin{array}{l}6.96^{c} \\
\pm 1.3\end{array}$ & $\begin{array}{c}0.71^{\mathrm{b}} \pm \\
0.35\end{array}$ & $\begin{array}{c}20.31^{\mathrm{d}} \pm \\
2.36\end{array}$ \\
\hline P1 & $\begin{array}{l}18.35^{b} \\
\pm 1.655 \\
\end{array}$ & $\begin{array}{c}0.51^{\mathrm{ab}} \\
\pm 0.2 \\
\end{array}$ & $\begin{array}{c}13.72^{\mathrm{ab}} \\
\pm 1.5\end{array}$ & $\begin{array}{l}7.34^{\mathrm{bc}} \\
\pm 1.25 \\
\end{array}$ & $\begin{array}{c}0.88^{\mathrm{ab}} \\
\pm .03 \\
\end{array}$ & $\begin{array}{c}23.26^{\mathrm{cd}} \\
\pm 2.21\end{array}$ \\
\hline P2 & $\begin{array}{c}17.73^{\mathrm{bc}} \\
\pm 1.5\end{array}$ & $\begin{array}{c}0.58^{\mathrm{ab}} \\
\pm .15 \\
\end{array}$ & $\begin{array}{c}13.87^{a b} \\
\pm 1.2 \\
\end{array}$ & $\begin{array}{l}7.77^{\mathrm{abc}} \\
\pm 1.15 \\
\end{array}$ & $\begin{array}{l}0.93^{\mathrm{ab}} \\
\pm 0.25 \\
\end{array}$ & $\begin{array}{l}23.7^{\mathrm{bc}} \\
\pm 2.11 \\
\end{array}$ \\
\hline P3 & $\begin{array}{c}17.41^{\mathrm{bc}} \\
\pm 1.5\end{array}$ & $\begin{array}{l}0.67^{\mathrm{ab}} \\
\pm 0.15 \\
\end{array}$ & $\begin{array}{c}13.95^{\mathrm{ab}} \\
\pm 1.0\end{array}$ & $\begin{array}{l}7.85^{\mathrm{abc}} \\
\pm 1.15 \\
\end{array}$ & $\begin{array}{c}0.98^{\mathrm{ab}} \\
\pm 0.3 \\
\end{array}$ & $\begin{array}{c}24.1^{\mathrm{abc}} \\
\pm 0.7\end{array}$ \\
\hline P4 & $\begin{array}{c}15.36^{c} \\
\pm 1.4 \\
\end{array}$ & $\begin{array}{l}0.78^{\mathrm{a}} \\
\pm 0.2 \\
\end{array}$ & $\begin{array}{c}14.75^{\mathrm{ab}} \\
\pm 0.75\end{array}$ & $\begin{array}{c}9.15^{\mathrm{ab}} \\
\pm 1.0 \\
\end{array}$ & $\begin{array}{l}1.2^{\mathrm{ab}} \\
\pm 0.2\end{array}$ & $\begin{array}{c}26.32^{a b c} \\
\pm 1.15\end{array}$ \\
\hline P5 & $\begin{array}{c}15.21^{\mathrm{c}} \\
\pm 1.4 \\
\end{array}$ & $\begin{array}{c}0.80^{\mathrm{a}} \pm \\
0.2\end{array}$ & $\begin{array}{l}15.1^{\mathrm{b}} \\
\pm 0.7 \\
\end{array}$ & $\begin{array}{c}9.38^{\mathrm{ab}} \\
\pm 1.0 \\
\end{array}$ & $\begin{array}{l}1.27^{a} \\
\pm 0.2 \\
\end{array}$ & $\begin{array}{c}26.8^{\mathrm{ab}} \\
\pm 1.1\end{array}$ \\
\hline P6 & $\begin{array}{c}14.91^{\mathrm{c}} \\
\pm 1.4 \\
\end{array}$ & $\begin{array}{l}0.83^{\mathrm{a}} \\
\pm 0.15 \\
\end{array}$ & $\begin{array}{l}15.3^{a} \\
\pm .07 \\
\end{array}$ & $\begin{array}{l}9.88^{a} \\
\pm 1.0 \\
\end{array}$ & $\begin{array}{l}1.34^{a} \\
\pm 0.2 \\
\end{array}$ & $\begin{array}{c}27.25^{\mathrm{a}} \\
\pm 1.1 \\
\end{array}$ \\
\hline LSD & 2.7699 & 0.3157 & 2.2467 & 1.9743 & 0.4609 & 3.0537 \\
\hline
\end{tabular}

means that the values followed by the same letter in the same a column are not - significantly different at $(P \leq 0.05)$

The results in table (5) showed that Hardness, Cohesiveness, Gumminess,Chewiness,Springiness and Adhesiveness of different sausage treatments were significantly $(p<0.05)$ affected by the type of pectin. Hardness of sausage treatments was significantly decreased by added pectin, where the lowest value of Hardness was recorded for P6 treatment followed by P5,P4,P3,P2,P1 and C, respectively. While the Cohesiveness, Gumminess,Chewiness,Springiness and Adhesiveness were significantly increased, where the lowest value of Cohesiveness, Gumminess, Chewiness, Springiness and Adhesiveness was found in the $C$ samples followed by $\mathrm{P} 1, \mathrm{P} 2, \mathrm{P} 3, \mathrm{P} 4, \mathrm{P} 5$ and $\mathrm{P} 6$, respectively. These results were in agreement with that reported by Osheba et al., (2013) who found that addition of pectin decreased the hardness and increased the Cohesiveness, Gumminess, Chewiness, Springiness and Adhesiveness of cooked meat sausage. On the other hand The treatments of the nanoparticles pectin samples were better when compared to the treatments of the ordinary pectin samples. This may be due to The small microreticulated fibers form an extremely stable gel which exhibit a reversible shear thinning (Bodner and Sieg,2009).This may be due to the fact that nanotechnology increases the surface area exposed to the nanoparticles pectin samples and thus increases its effectiveness in linking the meat sausage components (deliver polar, nonpolar, and amphiphilic functional ingredients as stated by Bilska et al., (2009)). 
And with increases the concentration of pectin increases the linking efficiency. Or it may be due to the increase in $\mathrm{pH}$ of the nanoparticles pectin samples as in table (3). Such trend was confirmed by Gençcelep et al.,(2017) who reported that pH had a profound effect on physical properties such as the water-holding capacity, tenderness and color of meat. Usually, a high pH $(\sim 6.80)$ is closely related to high shear force or gel strength in meat products. Therefore, $\mathrm{pH}$ was found to have an effect on the texture properties in any replacing beef with potato starch, which increased the hardness, adhesiveness, cohesiveness, gumminess and chewiness of raw and cooked meat emulsions .

Results presented in Tables (6) show the means scores of sensory evaluation (color, taste, odor, texture and overall acceptability) of some different cooked sausage treatments attributes affected by the type of pectin . It could be noticed that there were no significant differences $(P \leq 0.05)$ in color and odor of different treatments of the nanoparticles pectin samples and the treatments of the ordinary pectin samples and $C$ samples. On the other hand, it could be noticed that there were significant differences $(P \leq 0.05)$ in taste, texture and overall acceptability of different treatments of the nanoparticles pectin samples and the treatments of the ordinary pectin samples and C samples. Where P6 had the highest score of taste, texture and overall acceptability followed by P5,P4, P3,P2 ,P1 and C samples, respectively. This results confirmed with the obtained results in this study as in Tbles ( 5$)$.

Table 6. Sensory evaluation of different cooked sausage treatments attributes

\begin{tabular}{|c|c|c|c|c|c|}
\hline Treatments & Color & Taste & Odor & Texture & $\begin{array}{c}\text { Overall } \\
\text { acceptability }\end{array}$ \\
\hline C & $7.60^{\mathrm{a}}$ & $7.73^{\mathrm{b}}$ & $8.12^{\mathrm{a}}$ & $8.05^{\mathrm{c}}$ & $7.875^{\mathrm{a}}$ \\
& \pm 0.3 & \pm 0.33 & \pm 0.11 & \pm 0.2 & \pm 0.5 \\
\hline P1 & $7.60^{\mathrm{a}}$ & $7.86^{\mathrm{ab}}$ & $8.10^{\mathrm{a}}$ & $8.15^{\mathrm{bc}}$ & $7.922^{\mathrm{a}}$ \\
& \pm 0.27 & \pm 0.3 & \pm 0.13 & \pm 0.15 & \pm 0.3 \\
\hline P2 & $7.63^{\mathrm{a}}$ & $8.11^{\mathrm{ab}}$ & $8.11^{\mathrm{a}}$ & $8.20^{\mathrm{abc}}$ & $8.013^{\mathrm{a}}$ \\
& \pm 0.3 & \pm 0.31 & \pm 0.11 & \pm 0.15 & \pm 0.2 \\
\hline P3 & $7.66^{\mathrm{a}}$ & $8.12^{\mathrm{ab}}$ & $8.10^{\mathrm{a}}$ & $8.3^{\mathrm{abc}}$ & $8.045^{\mathrm{a}}$ \\
& \pm 0.28 & \pm 0.25 & \pm 0.1 & \pm 0.15 & \pm 0.21 \\
\hline P4 & $7.66^{\mathrm{a}}$ & $8.20^{\mathrm{ab}}$ & $8.10^{\mathrm{a}}$ & $8.33^{\mathrm{ab}}$ & $8.073^{\mathrm{a}}$ \\
& \pm 0.28 & \pm 0.28 & \pm 0.12 & \pm 0.18 & \pm 0.15 \\
\hline P5 & $7.67^{\mathrm{a}}$ & $8.25^{\mathrm{a}}$ & $8.11^{\mathrm{a}}$ & $8.40^{\mathrm{ab}}$ & $8.108^{\mathrm{a}}$ \\
& \pm 0.3 & \pm 0.3 & \pm 0.1 & \pm 0.1 & \pm 0.1 \\
\hline P6 & $7.69^{\mathrm{a}}$ & $8.35^{\mathrm{a}}$ & $8.1^{\mathrm{a}}$ & $8.45^{\mathrm{a}}$ & $8.148^{\mathrm{a}}$ \\
& \pm 0.2 & \pm 0.3 & \pm 0.11 & \pm 0.1 & \pm 0.1 \\
\hline LSD & 0.5158 & 0.5077 & 0.1828 & 0.2610 & 0.4521 \\
\hline
\end{tabular}

means that the values followed by the same letter in the same a column are not - significantly different at $(P \leq 0.05)$. 


\section{CONCLUSION}

It could be concluded from the results of this investigation that ordinary and nanoparticles pectin were found to have thixotropic behavior since apparent viscosity of samples contained pectin and pectin nanoparticles decreased with decrease the pectin concentration. The effect of different concentrations of pectin and pectin nanoparticles as linker the components of meat sausage, which improves the quality properties of the physicochemical and sensory products of investigated products. The results indicated also that the best water holding capacity (i.e., lowest value) and plasticity,cooking loss,cooking yield, emulsion stability, texture profile analysis and sensory evaluation was recorded in The treatments of the nanoparticles pectin samples compared to the treatments added of the ordinray pectin samples and $C$ samples, respectively. This study suggests these nanoparticles pectin have a potential use as successful colloids..

\section{REFERENCES}

1. Aitken, A., Casey, J. C., Penny, I. F. and Voyle, C. A. 1962. Effect of drying temperature in the accelerated freeze of prok. J. Sci. of Food Agric., 13(8):439448.

2. Badan Standardisasi Nasional. 1995. SNI 01-3820-1995. Syarat mutu sosis daging. Jakarta: Dewan Standarisasi Nasional.

3. Bilska, A., Rudzińska, M., Kowalski, R. and Krysztofiak, K. 2009. The effect of soy hydrolysates on changes in cholesterol content and its oxidation products in fine - ground model sausages. Acta Sci. Pol., Technol. Aliment. ,8( 3): 15-22.

4. Bodner, J.M. and Sieg, J. 2009. Ingredients in Meat Products: Properties, Functionality and Applications Springer Science + Business Media, LLC, Chapter 4:83-109.

5. Bourne, M. C. 2003. Food texture and viscosity: Concept and measurement. Elsevier Press, New York /London.

6. Cheftel, J.C., Cuq, J.L.and Lorient, D. 1985. Amino acids, peptides, and proteins. In O. R. Fennema (Ed.), Food Chemistry (nd cd.), Marcel Dekker Inc., New York, USA, $369 \mathrm{p}$.

7. Chen, H., Weiss J. and Shahidi, F. 2006. Nanotechnology in nutraceuticals and functional foods. Food Technol. ,60( 3):30-36.

8. Dipjyoti, S. and Suvendu, B. 2010. Hydrocolloids as thickening and gelling agents in food: a critical review. J Food Sci Technol ., 47(6):587-597.

9. Entsar, S. A. Osheba, A.S. and Sorour, M. A. 2012. Effect of Chitosan and Chitosan-Nanoparticles as Active Coating on Microbiological Characteristics of 
Fish Fingers. International Journal of Applied Science and Technology., 2(7): 158-169.

10. Gençcelep, H., Anıl, M. ,Sarıcaoğlu, F. T. and Ağar, B. 2017. The Effects of Different Modified Starches on Some Physical and Texture Properties Of Meat Emulsion. Gida The Journal Of Food, 42 (6):773-786.

11. Kim,K., Kim,J. H., Park,H., Kim,kiY., Park,K., Nam,H., Lee,S., Park,J. H., Park,R., Kim,I., Choi,K., Kim,S. Y., Park,K.and Kwon,I. C. 2010. Tumor-homing multifunctional nanoparticles for cancer theragnosis: Simultaneous diagnosis, drug delivery, and therapeutic monitoring. Journal of Controlled Release, 146, 219- 227.

12. Lech, O., Edward. P. and Suresh. N. 2010. Nanotechnologies In Food and Meat Processing. Acta Sci. Pol., Technol. Aliment., 9(4) : 401-412.

13. Li,J. and Huang,Q. 2012. Rheological properties of chitosantripolyphosphate complexes: Fromsuspensions to microgels Carbohydrate Polymers., 87: 16701677.

14. Liu, L., Fishman, M.L., Kost J. and Hicks, K.B. 2003. Pectin-based systems for colon-specific drug delivery via oral route. Biomaterials., 19: 3333-3343.

15. McClement, D.J. 2000. Comments on viscosity enhancement and depletion flocculation by polysaccharides. Food Hydrocoll., 14: 173-177.

16. Ockerman, H.W. 1985. Emulsfying capacity and stability Quality control of post mortem muscle tissue (nd ed.), (Vol. 2). The Ohio State University, Columbus, $\mathrm{OH}$, USA.

17. Osheba. A. S. 2013. Evaluation of Some Vegetal Colloids on the Quality Attributes of Beef Sausage .Adv. J. Food Sci. Technol., 5(6): 743-751.

18. Osheba. A. S. ,Sorour. M. A. and Entsar.S. A. 2013. Effect of Chitosan Nanoparticles as Active Coating on Chemical Quality and Oil

19. Uptake of Fish Fingers. Journal of Agriculture and Environmental Sciences 2(1),. 01-14

20. Pillay, V. and Fassihi, R. 1999. In vitro release modulation from crosslinked pellets for site-specific drug delivery to the gastrointestinal tract. II. Physicochemical characterization of calcium-alginate, calciumpectinate and calcium-alginate-pectinate pellets. J. Control Release,59:243-256. doi: 10.1016/S0168-3659(98)00197-7.

21. Praneet, O., Auayporn ,A., Tanasait ,N., Theerasak,R.and Uracha, R. 2008. Development and Characterization of Pectinate Micro/Nanoparticles for Gene Delivery. AAPS PharmSciTech., 9(1): 67-74. 
22. Rolin, P.C.,Whistler, R. L. and Bemiller,J. N. 1993. Industrial Gums: Polysaccharides and their Derivatives. New York: Academic. 257-293.

23. Sangeetha, S. , Harish,G. and Malay, K.S. 2010. International Journal of Pharma and Bio Sciences, 2.

24. SAS. 1996. SAS/STAT User's Guide, Version 8, SAS Institute Inc, Cary, NC.

25. Soloviev, V. E. 1966. Meat aging In "Food Industry" Pub., (Moscow) pp: 53-81, $82-164,242-303$.

26. Suderman, D.R., Wiker, J. and Cunningham, F.E. 1981. Factors affecting adhesion of coating to poultry skin. Effects of various protein and gum sources in the coating composition. Food Sci., 46: 1010-1011.

27. Tahmasebi,M., Labbafi, M., Emam-Djomeh, Z. and Yarmand, M.S. (2016). Manufacturing the novel sausages with reduced quantity of meat and fat: The product development, formulation optimization, emulsion stability and textural characterization. LWT-Food SCI Technol., 68: 76-84. http://dx.doi.org/10.1016/j.Iwt.2015.12.011.

28. Zorba, Ö., Gökalp, H.Y., Yetim, H. and Ockerman, H.W. 1993. Model system evaluations of the effects of different levels of $\mathrm{K}_{2} \mathrm{HPO}_{4}, \mathrm{NaCl}$ and oil temperature on emulsion stability and viscosity of fresh and frozen Turkish style meat emulsions. Meat Sci., 34: 145-161.

29. Williams, P.A . 2006. An overview of the structure-function relationship of hydrocolloids. In: Philips GO, Williams PA (eds) Gums and stabilizers for the food industry, vol 13. RSC Publ, Oxford, pp 15-29. 


\section{تأثير البكتين والجسيمات الناتوية للبكتين على بعض خواص الجودة لسجق اللحم}

\section{محمود فرحات سيد عو اد قدوس}

قسم بحوث تكنولوجيا اللحوم والأسماك - معهُ بحوث تكنولوجيا الأغذية - مركز البحوث الزراعية جيزة - مصر

يهدف هذا العمل الى بحث إمكانية استخدام الجسيمات النانوية للبكتين كمادة غروية نشطة في سجق اللحم .حيث تم در اسة تأثير تركيزات مختلفة من البكتين و الجسيمات النانوية البكتينية كغرويات

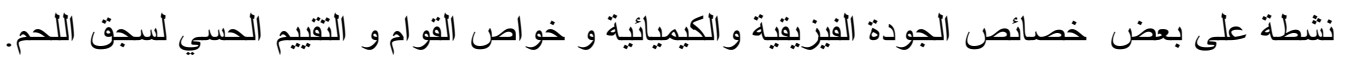

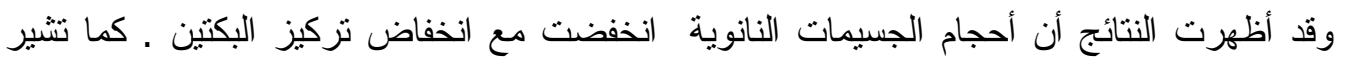

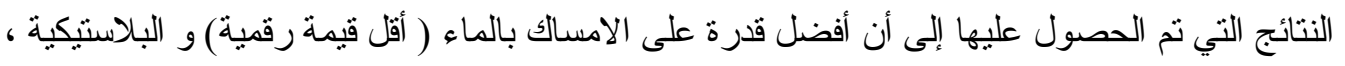

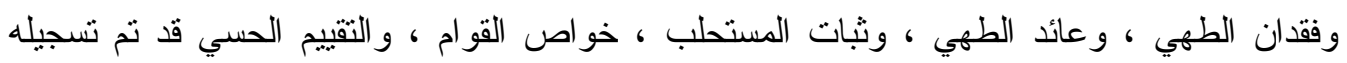

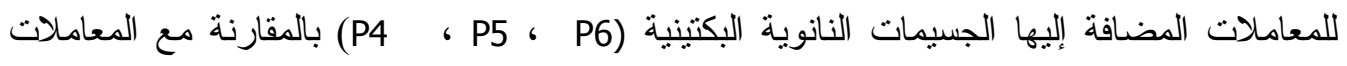
المضافة إليها البكتين العادى(P3 ، P2 و P1 ) و الكنترول (C) على التو الي. 

SOME QUALITY PROPERTIES OF MEAT SAUSAGE 